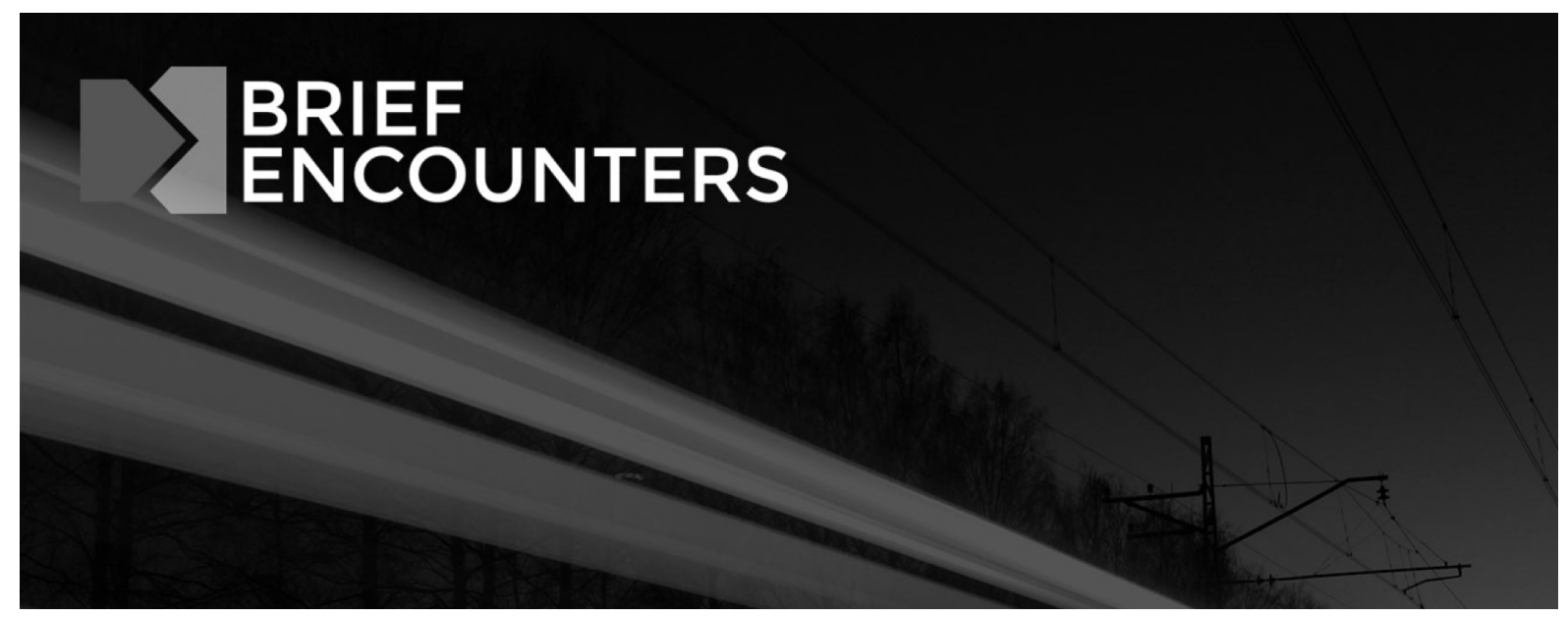

ISSN 2514-0612

Journal homepage: http://briefencounters-journal.co.uk/BE

Post-foundational Ontology and the Charge of Social Weightlessness in Radical Democratic Theory: A Response to Lois McNay's The Misguided Search for the Political

Author(s): Tom N. Henderson

Email: t.henderson@gold.ac.uk

Source: Brief Encounters Vol.1, No. 1 (Feb 2017)

URL: http://briefencounters-journal.co.uk/BE/article/view/23/

DOI: http://dx.doi.org/10.24134/be.v1i1.23

(C) Tom N. Henderson, 2017

License (open-access): This is an open-access article distributed under the terms of the Creative Commons Attribution License 4.0, which permits unrestricted use, distribution, and reproduction in any medium, provided the original work is properly cited. No warranty, express or implied, is given. Nor is any representation made that the contents will be complete or accurate or up to date. The publisher shall not be liable for any actions, claims, proceedings, demand or costs or damages whatsoever or howsoever caused arising directly or indirectly in connection with or arising out of the use of this material.

Brief Encounters is an open access journal that supports the dissemination of knowledge to a global readership. All articles are free to read and accessible to all with no registration required. For more information please visit our journal homepage: http://briefencounters-journal.co.uk/BE.

In association with 


\section{Post-foundational Ontology and the Charge of Social Weightlessness in Radical Democratic Theory: \\ A Response to Lois McNay's The Misguided Search for the Political}

Tom N. Henderson

\section{Introduction}

Radical democracy has emerged over the last three decades as a loosely affiliated school of thought seeking to face new challenges that have arisen for political theory and practice since the final years of the Cold War. While this period can be characterised as one of crisis for the Western academic and political left - from the explanatory obsolescence of Marxist orthodoxy and the demise of Actually Existing Socialism, to the rise of non-class-based identity politics - it has also led to a crisis for politics more generally. ${ }^{1}$ Rather than the end of history, 1989 marked the ultimate ascendency of neo-liberalism, an ostensibly universal consensual form of democracy based on market logic. Reducing all differences to immanently soluble technical problems, any antagonistic conception of politics, concerned with the interplay of power relationships, was declared irrelevant and unhelpful if peace and prosperity were to be pursued. Since then, peace and prosperity have proved elusive and inequitable, while antagonisms and stark power differentials have only grown. The apolitical neo-liberal version of democracy serves to mask and sustain the inequalities it produces, even while unable to account for them, on grounds of economic necessity. ${ }^{2}$

In response, radical democracy posits a resolutely political form of democracy that both accounts for power and antagonism, and seeks to unmask and critique the injustices of

\footnotetext{
${ }^{1}$ Adrian Little and Moya Lloyd, 'Introduction', in The Politics of Radical Democracy, ed. by Adrian Little and Moya Lloyd (Edinburgh: Edinburgh University Press, 2009), pp. 1-11.

2 Lars Tønder and Lasse Thomassen, 'Introduction: Rethinking Radical Democracy between Abundance and Lack', in Radical Democracy: Politics between Abundance and Lack, ed. by Lars Tønder and Lasse Thomassen (Manchester: Manchester University Press, 2005), pp. 1-13.
} 
neo-liberalism. Conceptually, this has involved a renewed focus on 'the political,' as not only autonomous from, but also primary to the social sphere, which includes 'politics' in commonsense terms. Such a move follows in the footsteps of, among others, Carl Schmitt, who reasserted the need to understand the political as political, against the depoliticising forces of interwar German political liberalism. ${ }^{3}$ By locating the political at, or as, the deepest level of human being, this theoretical approach can rightly be labelled 'political ontology.' It is this focus on political ontology in radical democratic theory that Lois McNay, in her book The Misguided Search for the Political: Social Weightlessness in Radical Democratic Theory, accuses of counterproductively leading this school of thought away from the practical challenges they are supposed to confront. ${ }^{4}$

In what follows, I will argue, using Oliver Marchart's understanding of ontology as 'political difference,' that, while McNay's concerns may be valid in reference to the particular radical democrats she has in her sights, political ontology per se is not necessarily the cause of the problem. ${ }^{5}$ Moreover, I will suggest that the alternative she puts forward as the basis for political theory, namely an embodied disclosing critique of social suffering, could serve to supplement the least developed element of Marchart's ontological approach: the mediation between the political and the social. I will argue that McNay's overall argument need not be defended against, but can instead be put to work to enhance and refine the political ontology of radical democracy in the name of its original purpose: to challenge, theoretically and practically, apolitical neo-liberal forms of democracy and their consequences.

\footnotetext{
${ }^{3}$ Carl Schmitt, The Concept of the Political, trans. by George Schwab (Chicago: University of Chicago Press, 1996).

${ }^{4}$ Lois McNay, The Misguided Search for the Political: Social Weightlessness in Radical Democratic Theory (Cambridge: Polity Press, 2014).

${ }^{5}$ For a discussion of the distinction between politics and the political, see Oliver Marchart, Post-Foundational Political Thought: Political Difference in Nancy, Lefort, Badiou and Laclau (Edinburgh: Edinburgh University Press, 2008).
} 


\section{McNay's Argument}

McNay's critique of radical democracy is made on the basis that it has failed to live up to its own standards. For McNay, what makes radical democracy worth fighting for is its commitment to the critique of power. 'Radical democrats', she observes, 'maintain [...] that thought about emancipatory norms cannot be disconnected from an account of existing social inequalities,' thus locating the theorist as an active participant in, rather than passive observer of, political struggle. ${ }^{6}$ We will see that this is not always the case.

Her overall argument is as follows. Despite its purported concern for the critique of power, radical democratic theory has become divorced from the quotidian experience of social life, and particularly of its negative and constraining features, which inhibit political action in practice. The excessively abstracting tendency this field of thought exhibits comes not from an avowed idealism of the sort embraced by analytic philosophers like John Rawls, but from its over-reliance on an ontological conception of the political. ${ }^{7}$ For McNay, this entails the attempt to distil an essential understanding of the political from which to derive models of democracy. This in turn produces a theoretical hierarchy with the ontological (the political, in an abstract sense) at the top, and the ontic (the social, in a concrete sense) at the bottom. ${ }^{8}$ As a result, actual social power dynamics, being firmly ontic phenomena, are disregarded. Political agency becomes understood no longer in terms of these dynamics, despite their instrumentality in inhibiting or enabling it, but is simply equated with the abstract possibilities inherent in the indeterminacy of political ontology. This leaves no room for analysing how and why political action does or does not take place in a given situation, nor for accounts of the lived experience of those agents or would-be agents. ${ }^{9}$ In the last instance,

\footnotetext{
${ }^{6}$ McNay, pp. 6-7.

7 Ibid., p. 11.

8 Ibid., p. 69.

9 Ibid., p. 15.
} 
the search for the political is misguided because there is no foundational essence of the political to be discovered. ${ }^{10}$

McNay's argument is made in reference to one set of radical democrats: Chantal Mouffe, Linda Zerilli and Wendy Brown, Jacques Rancière, and William Connolly and James Tully. Marchart, meanwhile, uses a different but equally ontologically informed set - Jean-Luc Nancy, Claude Lefort, Ernesto Laclau, and Alain Badiou - to argue instead for a non-dualistic, non-hierarchical understanding of the relationship between the ontic and the ontological, in which the social and the political are in fact shown to be mutually constitutive. ${ }^{11}$ McNay does cite this work in passing, but I will now argue that, in light of it, the social weightlessness of McNay's thinkers stems not from the fact of their frameworks' ontological character, but from their failure, in different ways, to adequately account for the relationship between the social and the political, this relationship being a crucial element of Marchart's argument.

\section{Being as Difference Versus Weak Affirmation}

The core of Marchart's argument is his development of Heidegger's 'ontological difference' into 'political difference.' As he explains, for Heidegger, the ontological - that which is supposed to serve in philosophy as the ultimate, unchanging ground of Being - is in fact in a constant motion of withdrawal, as a consequence of the historical weakening of the supposedly firm metaphysical foundations of modernity, such as History, Reason or Progress. This withdrawal produces an irreducible difference - the ontological difference - between the ontic, the realm of particular beings and phenomena, and the ontological ground upon which they try to stand. This difference itself becomes the only remaining ground to speak of, so Being must be conceived of as difference, rather than as firm foundation. For Marchart, this is the common ontological framework of his radical democrats' conceptions of the political,

\footnotetext{
10 Ibid., p. 217.

${ }^{11}$ See Marchart, Post-Foundational Political Thought.
} 
which serves as the contingent, contestable or antagonistic ground of politics and the social. He therefore recasts the 'ontological difference,' between the ontological and the ontic, as the 'political difference,' between the political and politics..$^{12}$

This differs in two related ways from McNay's understanding of political ontology. Firstly, she follows Tønder and Thomassen's taxonomical distinction between political ontologies of lack or negativity, and those of abundance or positivity. ${ }^{13}$ Further, she follows White in understanding any attachment to these ontologies, particularly positive ones, as tempered by a 'weakness' that guards against their being mistaken for solid ground. ${ }^{14}$ For McNay, this is what leads to social weightlessness, or at least a lack of politically committed social critique, in Connolly's work. While his positive ontology should incorporate an immanent, materialist analysis of individuals' lived practices, to prevent the reification of such analysis into irrefutable ground - enter here White's figure of weakness - Connolly calls for an 'ethos of generosity,' an acknowledgement of the contestability of one's views. McNay rightly identifies the inherent conservatism of such an ethos, meekly affirmative of the status quo and necessarily averse to arguing for an alternative. ${ }^{15}$

But such depoliticised quietism is not the inevitable consequence of understanding the political ontologically: the 'ethos of generosity' is necessary only to prevent the slip from an ontology of abundance into one of solid foundation. McNay does acknowledge this, and Dean, who rejects White's weakness thesis, but upon whose argument McNay here partly relies, sees how an affirmative ontology such as Connolly's could still 'inspire a political drive to struggle for change.'16 The fact that it does not stems from its straightforward positivity and the subsequent attempt to prevent its condensation into naturalistic foundationalism. An

\footnotetext{
12 Ibid., Post-Foundational Political Thought, pp. 18-25.

${ }^{13}$ McNay, p. 172.

14 Stephen K. White, Sustaining Affirmation: The Strengths of Weak Ontology in Political Theory (Princeton: Princeton University Press, 2000), pp. 6-8.

${ }^{15}$ McNay, pp. 174-178.

${ }^{16}$ Ibid., p. 180; Jodi Dean, 'The Politics of Avoidance: The Limits of Weak Ontology', The Hedgehog Review, 7.2 (2005), 55-65 (p. 58).
} 
equivalent risk presents itself in ontologies of lack, which may, if unchecked, lead to the valorisation of death and destruction. ${ }^{17}$ An ontology of difference, however, while not immune from being hypostatised into, for instance, a politics of separatism, has the advantage that contingency and contestability are built into its fundamental premises, avoiding the need to introduce the politically deadening factor of weakness a posteriori. ${ }^{18}$ This lends it greater potential to be wielded for more critical purposes.

\section{The Political as Universal Essence?}

The second problem McNay identifies in ontological radical democratic thought is its positing of the political as an essentialised, ahistorical concept transcending social actuality. She cites, for example, Mouffe's idea of the inherence and universality of antagonism. ${ }^{19}$ Whether or not Mouffe can be said to make this claim, an ontology of political difference would not allow for such a move. Firstly, being post-foundational, rather than foundational or anti-foundational, it is not an ahistorical ontology. ${ }^{20}$ That is not to imply that it denotes a sequential move from one discrete era to another. Rather, as both Laclau and Vattimo each argue in their Heideggerian ontologies, the withdrawal of foundations is a moment both internal to modernity - they were never solid in the first place - and constitutive of what could in the loosest sense be called post-modernity, as human beings struggle to come to terms with this realisation. ${ }^{21}$ That is to say, the political difference is temporally specific.

Secondly, its emergence in time is also an emergence in space. One of the sets of historical events in which the political difference began to disclose itself is, for Marchart,

\footnotetext{
17 Oliver Marchart, 'The Absence at the Heart of Presence: Radical Democracy and the "Ontology of Lack"', in Radical Democracy: Politics between Abundance and Lack, ed. by Lars Tønder and Lasse Thomassen (Manchester: Manchester University Press, 2005), pp. 17-31 (p. 28).

18 Ibid.

${ }^{19}$ McNay, p. 70.

${ }^{20}$ Marchart, Post-Foundational Political Thought, pp. 12-13.

${ }^{21}$ Ernesto Laclau, Emancipation(s) (London: Verso, 2007), pp. 101-103; Marchart, Post-Foundational Political Thought, p. 26; Gianni Vattimo, Nihilism and Emancipation: Ethics, Politics, and Law, ed. by Santiago Zabala, trans. by William McCuaig (New York: Columbia University Press, 2004), p. 50.
} 
following Lefort, the European democratic revolutions, symbolised by the decapitation of Louis XVI of France. This placed contestability and contingency, not divinely sanctioned monarchical authority, at the heart of political organisation. ${ }^{22}$ For European politics after these events:

every regime - democratic or not - [has] to come to terms with the absence of an ultimate ground and with the unbridgeable chasm of division that opens up in place of [any prior] ground. ${ }^{23}$

But in no way does this make any claims about the inherent political character of all human existence always and everywhere. The de facto universality of European democracy, which is now the model for almost all forms of state political organisation, is wholly contingent and historically instituted.

Indeed, only from this contingency can Marchart move from the language of Being in general (of which we can no longer speak, as such) to that of the political. What the political difference introduces is the possibility (although not the guarantee) that society could be organised democratically; our present experience of Being (as difference), in our particular time and place, can be understood as that of the political. ${ }^{24}$ This quasi-transcendental positing of political ontology as fundamental ontology is not the kind of metaphysical sophistry that McNay rightly denounces; rather than a statement about the essential character of the political (this, indeed, does not exist) it is one about the latently political, that is, contingent, contestable, antagonistic, groundless/self-founding character of anything that today can be understood in terms of Being. To speak of 'the political' in ontological terms is to recast Being as difference, and to identify this difference with the political. ${ }^{25}$

\footnotetext{
22 Marchart, Post-Foundational Political Thought, p. 93.

23 Ibid., Post-Foundational Political Thought, pp. 95-96.

24 Ibid., Post-Foundational Political Thought, pp. 165-172.

25 Ibid., Post-Foundational Political Thought, p. 172.
} 


\section{The Mutual Constitution of The Political and The Social}

Understood as the political, Being not only provides the groundless ground of the social, but is itself constituted by actual ontic events, both historically and presently. The relationship between the political and the social, where these events occur, must therefore be understood as mutually constitutive, not hierarchical. Indeed, it is precisely because it is impossible to construct a pure general ontology untainted by the ontic that a regional ontology, contaminated by the ontic, can and must ascend to the place of a general ontology. For Marchart this itself is a political decision, 'an intervention from the ontic side of politics [that is, the social] into the depoliticized field of philosophy. ${ }^{26}$

McNay, who does acknowledge this step of Marchart's argument, is therefore right to be concerned when she observes cases, specifically those of Mouffe and Rancière, where the social becomes bracketed, and, once a satisfactory abstract understanding of the political has been obtained, these brackets become permanent, lest their contents contaminate it. ${ }^{27}$ It is not that these thinkers do not appreciate the importance of connecting their understandings of the political to social practice; indeed, Rancière shuns, or at least disavows, the framework of ontology, in favour of a more socially constituted political theory. But by subordinating the experience of the social to their rigid, anti-sociological definitions of the political, both Mouffe and Rancière become unable to engage with it. ${ }^{28}$ Suffice it to say that this particular path to social weightlessness is anything but a necessary consequence of theorising the political ontologically. To ignore the social and its relationship to the political, as do Mouffe and Rancière, is surely to empty the latter category of any weight too.

\footnotetext{
26 Ibid., Post-Foundational Political Thought, p. 171.

${ }^{27}$ McNay, p. 95, p. 215.

28 Ibid., p. 148.
} 


\section{Indeterminacy and Agency}

The final accusation McNay makes of ontological radical democratic theory is its equation of indeterminacy with agency. Here, she observes, it is assumed that once the ultimate indeterminacy at the heart of (political) Being has been recognised, anyone should now be free to exercise their political agency unfettered. There are obvious problems with this; McNay cites Bourdieu's concern with the, often internalised, obstacles preventing people from acting in their own interests, and registers surprise 'that radical democrats do not attend more closely to the depoliticizing effects of symbolic violence and instead take political agency as an unproblematic given.'29 As Hoy succinctly puts it, in light of the infinite indeterminacy of being, '[t]he task then becomes to explain why a thousand possibilities are not simply actualized, and why instead societies manage to be fairly stable.'30

This task is avoided for various reasons by the theorists McNay cites: for Mouffe's theory, cut off from social reality, it is convenient to assume that social agents will simply proceed according to the logic of the political; for Rancière, his underlying presumption of equality elides with an unspoken presumption of agency, failing to consider that 'agency is not a capacity that is evenly distributed across all subordinated groups,' and that 'the poor' cannot always 'speak and act on their own behalf.' ${ }^{31}$ Meanwhile, for post-identity feminists Brown and Zerilli, the anti-subjectivist impulse to leave behind the fragmenting parochial concerns of identity, which obsess over trauma and victimhood, in favour of broader political aims, simultaneously leaves behind any account of suffering that may shed light on practical obstacles to agency. Instead they settle with an abstract notion of agency stemming from the same celebrated indeterminacy that deconstructs identity claims. ${ }^{32}$

\footnotetext{
29 Ibid., p. 162, p. 208.

30 David Couzens Hoy, Critical Resistance: From Poststructuralism to Post-Critique (Cambridge, Mass: MIT Press, 2004$),$ p. 15.

${ }^{31}$ McNay, p. 85, pp. 162-163.

32 Ibid., pp. 100-103, p. 115.
} 
Once again, in none of these cases is social weightlessness a necessary or direct consequence of the fact that these thinkers adopt ontological frameworks; it goes against the crucial mutually constitutive relationship between the social and the political. Indeed, for Marchart, echoing Laclau's navigation between voluntarism and determinism, this is crucial for post-foundationalism: whilst '[a]t no point do we encounter a solid anchorage for our activities, [...] no voluntarism follows from this, as we never sail on a sea without waves.'33 Nonetheless, neither provides a satisfactory account of these impeding waves, aside from some vague references to phenomenological sedimentation, leaving this corner of their theories unfurnished. It is precisely out of McNay's proposed remedy to social weightlessness, to which I will now turn, that a possible way of understanding this socialpolitical relationship emerges. ${ }^{34}$

\section{Interpretation, Embodiment and the Critique of Social Suffering}

The approach McNay proposes as the basis of a politically committed radical democracy combines Bourdieu's critique of social suffering with Honneth's version of disclosing critique. Briefly, building on his more well-known idea of social habitus, Bourdieu's critique aims to '[render] visible those oppressions and injustices that remain below the threshold of public perception' as a result of symbolic violence that both oppresses and silences social actors. ${ }^{35}$ Honneth, meanwhile, integrates this de-essentialised understanding of suffering into a disclosing social critique of the sort the original critical theorists of the Frankfurt School set

\footnotetext{
33 David Howarth, 'Hegemony, Political Subjectivity, and Radical Democracy', in Laclau: A Critical Reader, ed. by Simon Critchley and Oliver Marchart (London: Routledge, 2004), pp. 256-76 (p. 264); Ernesto Laclau and Chantal Mouffe, Hegemony and Socialist Strategy: Towards a Radical Democratic Politics, 2nd edn (London: Verso, 2001), p. 112; Marchart, PostFoundational Political Thought, pp. 3-4.

${ }^{34}$ See above, and Oliver Marchart, 'Institution and Dislocation: Philosophical Roots of Laclau's Discourse Theory of Space and Antagonism', Distinktion: Scandinavian Journal of Social Theory, 15.3 (2014), 271-82 <https://doi.org/10.1080/1600910X. 2014.966272> [accessed 12 July 2016] (p. 275).

35 McNay, p. 43.
} 
out to undertake. ${ }^{36}$ For McNay, by deriving 'emancipatory norms' from social practices rather than abstract logic, a:

phenomenology of suffering significantly expands a mainstream account of social justice by uncovering neglected types of social misery that arise from normalized structural inequalities. ${ }^{37}$

An obvious criticism of this approach, to which Bourdieu was no stranger, is that it promotes a paralysing miserabilism, offering no hope of political emancipation. Against this, McNay argues that it provides a necessary foil to the all-too-easy romanticisation of subaltern agency and challenges the fetishisation of indeterminacy 'as an apodictic source of radical politic[s].'38 In sum, it casts into relief:

discontinuity between [...] the abstract negativity of non-identity [...] that informs ideas of progressive ethical practice and [...] the social negativity of non-identity as experiences of isolation, resignation and disempowerment. ${ }^{39}$

Suffering, then, is not to be understood moralistically or in generalised existential terms, but rather as 'a political category, where certain generic types of social suffering are [seen as] the outcome of asymmetrical relations of power.' 40 Moreover, as a phenomenological approach, it is the experience of suffering that is the concern here: embodied social practices, not just ideas about them. ${ }^{41}$

A second, subtler criticism is that, as a phenomenology, this approach is so immanentist that it risks succumbing to the exact opposite of social weightlessness, reducing political critique to immediate, particular subjectivity. This would sacrifice the political in favour of the social, rather than mediating between the two. While not addressing this

\footnotetext{
${ }^{36}$ Ibid., p. 47, p. 209.

37 Ibid., pp. 47-48.

38 Ibid., p. 54, p. 93.

39 Ibid., p. 111.

40 Ibid., p. 210.

41 lbid., p. 208, p. 216.
} 
directly, McNay does inadvertently indicate one solution by framing her approach in terms not only phenomenological but hermeneutical. She does so on the basis that hermeneutics bypasses debates concerning idealism and realism, since it 'stresses the ineluctably situated [non-ideal] nature of normative judgements' while also recognizing that 'the world is always already pre-interpreted; there is no neutral, value-free standpoint on social "reality."'42

This harks back to Heidegger's ontology, in which, since 'there is nothing to Being itself,' hermeneutics is the only adequate form of ontological thinking, an activity that consists in the interpretation of, and within, the 'thrown' context of human being (Dasein).43 Honneth's figure of disclosure finds its roots here too, as interpretation is precisely the disclosure of the groundless truth of Being. ${ }^{44}$ Indeed, McNay's hermeneutics resembles what Vattimo calls an 'ontology of actuality,' a way to apprehend Being that takes its 'summons [...] from the world, never from a motivation internal to the logic of [...] philosophical discourse.'45 While for Vattimo an ontology of actuality offers an interpretation 'of the ongoing historical process and [...] of its positive potential,' it could equally include the negative stultifying aspects of social actuality that inhibit the realisation of political potential, as per Bourdieu's critique of social suffering. ${ }^{46}$

McNay's is not a conventional hermeneutics, however. For Heidegger, the birth of the discipline proper involved its departure from phenomenology, making the former a purely textual activity, emptied of bodies, materiality, and experience. ${ }^{47}$ Although Vattimo is concerned in recent work with the interpretative potential of weak and marginalised

\footnotetext{
42 Ibid., p. 210.

${ }^{43}$ Martin Heidegger, cited in Vattimo, Nihilism and Emancipation, p. 95; Gianni Vattimo and Santiago Zabala, Hermeneutic Communism: From Heidegger to Marx (New York: Columbia University Press, 2011), p. 87, pp. 92-93; see Howarth, p. 268 on the relationship between thrownness and Laclau's notion of dislocation.

44 Vattimo and Zabala, p. 22.

${ }^{45}$ Gianni Vattimo, Farewell to Truth, trans. by William McCuaig (New York: Columbia University Press, 2011), p. 24.

${ }^{46}$ Vattimo, Nihilism and Emancipation, p. 88.

47 Richard Kearney, 'The Wager of Carnal Hermeneutics', in Carnal Hermeneutics, ed. by Richard Kearney and Brian Treanor (New York: Fordham University Press, 2015), pp. 15-56 (pp. 16-17).
} 
populations, material experience remains conspicuously absent. ${ }^{48}$ But by founding her hermeneutics on interpretations of embodied suffering, McNay reunites the two disciplines, in a move close to Richard Kearney's recent formulation of 'carnal hermeneutics,' following Irigaray and the later Ricoeur's return to the flesh. Put succinctly, this involves the relocation of the sensate body as the primary site of hermeneutics, while still retaining the mediating function of Heidegger's hermeneutics between Being and beings, which is missing from phenomenology. 49

Inadvertently then, the approach that McNay proposes, if understood in terms of Vattimo's ontology of actuality and Kearney's carnal hermeneutics, could not be more apt a framework for understanding the mutual constitution of the social and the political, providing the missing piece of Marchart's political ontology.

\section{Conclusion}

I have argued that McNay's book does not so much make the case for the abandonment of the ontological approach to the political, as for it to be more finely honed and developed as a critical tool for political theory and practice. Overall, her argument is clearly useful in the critique of the specific authors she targets, but the standards against which she holds them can in fact be best met via a properly post-foundational political ontology. In terms of the general status of the ontological, the way in which this is translated into the concept of the political, and the question of universality versus temporal and spatial specificity, Marchart's notion of the political difference has been found to overcome most of the problems McNay identifies in her authors, showing that it is not the ontological approach per se that is the problem, so much as the way in which their particular approaches construe the relationship

\footnotetext{
${ }^{48}$ See Vattimo and Zabala.

${ }^{49}$ Kearney, 'The Wager of Carnal Hermeneutics', p. 54; See also, Richard Kearney, 'What Is Diacritical Hermeneutics?', Journal of Applied Hermeneutics, 1.1 (2011), 1-14 <http://jah.journalhosting.ucalgary.ca/jah/index.php/jah/article/view/6> [accessed 12 July 2016].
} 
between the political and the social. When it comes to the problem of equating agency with indeterminacy, while again not found to be a necessary consequence of an approach such as Marchart's, McNay's critique does reveal a conspicuous thinness on this topic. The solution she proposes, of an interpretative, embodied disclosing critique of social suffering, was found not only to operate within the same broadly Heideggerian framework as Marchart and related thinkers, but moreover to supplement their thought by reintroducing the hermeneutic dimension of Heidegger's ontology, and furthermore, reintroducing the body to hermeneutics.

McNay's contribution to the ontological thinking of the political in radical democratic thought should not be understated. While this appears to go directly against the intentions of her book, it must be acknowledged that she is not opposed to the overall endeavour of radical democracy, nor its transcendental turn as such. ${ }^{50}$ Perhaps the greatest achievement of her argument is to help radical democracy live up to its own standards. Meanwhile, I have not attempted to deny the existence of the problem of social weightlessness; McNay identifies very real and concerning tendencies within the field of radical democracy. The way forward, then, must not be to abandon the ontological framework, nor to remain unaware of the dangers of over-abstraction and the detachment of theory from practice. The primary task of political theory can still be the search for the political, but this search must begin with the embodied experience of actual social beings.

\footnotetext{
50 McNay, p. 4.
} 


\section{Bibliography}

Dean, Jodi, 'The Politics of Avoidance: The Limits of Weak Ontology', The Hedgehog Review, $7.2(2005), 55-65$

Howarth, David, 'Hegemony, Political Subjectivity, and Radical Democracy', in Laclau: A Critical Reader, ed. by Simon Critchley and Oliver Marchart (London: Routledge, 2004), pp. 256-76

Hoy, David Couzens, Critical Resistance: From Poststructuralism to Post-Critique (Cambridge, Mass: MIT Press, 2004)

Kearney, Richard, 'The Wager of Carnal Hermeneutics', in Carnal Hermeneutics, ed. by Richard Kearney and Brian Treanor (New York: Fordham University Press, 2015), pp. 15-56 <https://doi.org/10.5422/fordham/9780823265886.001.0001> [accessed 12 July 2016]

__, 'What Is Diacritical Hermeneutics?', Journal of Applied Hermeneutics, 1.1 (2011), 1-14 <http://jah.journalhosting.ucalgary.ca/jah/index.php/jah/article/view/6> [accessed 12 July 2016]

Laclau, Ernesto, Emancipation(s) (London: Verso, 2007)

Laclau, Ernesto, and Chantal Mouffe, Hegemony and Socialist Strategy: Towards a Radical Democratic Politics, 2nd edn (London: Verso, 2001)

Little, Adrian, and Moya Lloyd, 'Introduction', in The Politics of Radical Democracy, ed. by Adrian Little and Moya Lloyd (Edinburgh: Edinburgh University Press, 2009), pp. 1-11 Marchart, Oliver, 'Institution and Dislocation: Philosophical Roots of Laclau's Discourse Theory of Space and Antagonism', Distinktion: Scandinavian Journal of Social Theory, 15.3 (2014), 271-82 <https://doi.org/10.1080/1600910X.2014.966272> [accessed 12 July 2016] 
—_, Post-Foundational Political Thought: Political Difference in Nancy, Lefort, Badiou and Laclau (Edinburgh: Edinburgh University Press, 2008)

- 'The Absence at the Heart of Presence: Radical Democracy and the "Ontology of Lack"', in Radical Democracy: Politics between Abundance and Lack, ed. by Lars Tønder and Lasse Thomassen (Manchester: Manchester University Press, 2005), pp. 17-31

McNay, Lois, The Misguided Search for the Political: Social Weightlessness in Radical Democratic Theory (Cambridge: Polity Press, 2014)

Schmitt, Carl, The Concept of the Political, trans. by George Schwab (Chicago: University of Chicago Press, 1996)

Tønder, Lars, and Lasse Thomassen, 'Introduction: Rethinking Radical Democracy between Abundance and Lack', in Radical Democracy: Politics between Abundance and Lack, ed. by Lars Tønder and Lasse Thomassen (Manchester: Manchester University Press, 2005), pp. 1-13

Vattimo, Gianni, Farewell to Truth, trans. by William McCuaig (New York: Columbia University Press, 2011)

—, Nihilism and Emancipation: Ethics, Politics, and Law, ed. by Santiago Zabala, trans. by William McCuaig (New York: Columbia University Press, 2004)

Vattimo, Gianni, and Santiago Zabala, Hermeneutic Communism: From Heidegger to Marx (New York: Columbia University Press, 2011) <https://doi.org/10.7312/vatt15802> [accessed 12 July 2016]

White, Stephen K., Sustaining Affirmation: The Strengths of Weak Ontology in Political Theory (Princeton: Princeton University Press, 2000) 